Analysing success criteria for ict projects

Peer-reviewed author version

MILIS, Koen \& VANHOOF, Koen (2006) Analysing success criteria for ict projects.

In: 7th International Conference on Fuzzy Logic and Intelligent Technologies in Nuclear Science. p. 343-350..

DOI: $10.1142 / 9789812774118 \_0050$

Handle: http://hdl.handle.net/1942/1372 


\title{
ANALYSING SUCCESS CRITERIA FOR ICT PROJECTS
}

\author{
KOEN MILIS \\ EHSAL, European University College Brussels, \\ Centre for external cooperation, \\ Campus Economische Hogeschool, \\ Stormstraat 2, 1000 Brussels \\ KOEN VANHOOF \\ Transportation Research Institute (IMOB), \\ Universiteit Hasselt, \\ Wetenschapspark 5 bus 6, 3590 Diepenbeek
}

\begin{abstract}
Since the 1960's many authors accepted the triple constraints (time, cost, specification) as a standard measure of success and this still appears to be extremely important in evaluating the success of ICT (information communication technology) projects. However, an ICT project cannot always be seen as a complete success or a complete failure. Moreover, the parties involved may perceive the terms "success" or "failure" differently.

A quasi-experiment (gaming) was developed in order to determine the measures for success used by the different parties involved to judge an ICT project. The results of this quasi experiment were analysed using aggregation theory and validated by probabilistic feature models. In general the figures do not contradict.

This research indicates that the impact of the triple constraints on the judgement of success is rather small. Other criteria, as there are user happiness and financial or commercial success are far more important. Surprisingly, whether or not a project was able to meet the predefined specifications was of little importance for the appreciation of the project's success.
\end{abstract}

Keywords: Multi criteria analysis, gaming, project management and scheduling

\section{Introduction}

In order to lead an ICT project towards high levels of success, a manager should know the criteria by which success is measured (i.e. success criteria). Fulfilling these criteria should be the manager's prime concern.

Since the 1960's many authors accepted the triple constraints (time, cost, specification) as standard success criteria. It is assumed that if a projects completion time exceeds its due date or expenses overrun the budget, or outcomes do not satisfy a company's predetermined specifications, the project is a failure (Ingram, 2000; Wright, 1997; Turner, 1993).

However, determining whether an ICT-project is a success or a failure is far more complex (Belassi \& Tukel, 1996). Unlike a construction project, an ICT 
project cannot always be seen as completely successful or completely failed (Wateridge, 1998). Moreover, different parties involved (e.g. management, projectteam, users, supporter, stakeholders) might perceive the project's success differently (Pinto \& Slevin, 1989). But even among individuals of the same party, opinions might vary, since every individual has his/her own set of criteria against which the project is measured and these may be very subjective (Fowler \& Walsh, 1999). Furthermore, not every criterion can be measured at the same time. Some criteria can only be assessed long after the determination of the project, as for example the financial or commercial success of an ICT implementation (Wateridge, 1996).

The aim of the research is to determine the set of success criteria used by the different parties involved in an ICT project.

\section{Research design}

In opposite to most studies on the subject, a quantitative approach was selected. The data was gathered using a type of experiment ${ }^{*}$, referred to as gaming. The participants of the "game" were asked to rate the success of ICT projects, based on information (i.e. project descriptions) provided by the researchers.

Seven possible success criteria were selected based on a literature review (Milis \& Mercken, 2001). The list of criteria existed out of the triple constraints, extended with four other criteria: On time, Within budget, To specification, Users happiness, Projectteam happiness, Management happiness, Financial or commercial success.

Selected experts were all well acquainted with ICT projects and were either employees of one of the two large electricity-distributing companies that were participating, or consultants working for these companies. Based on the role the different experts fulfilled, they could be classified into four groups : managers, project team members - no benefactors, project team members - no benefactors, end-users.

During five consecutive days, the experts received an email with five project descriptions and were asked to judge the project's success based solely on the information provided. They were asked to reply by email within 24 hours (e.g. before the next set of descriptions arrived) to avoid comparison between

\footnotetext{
"Note that due to the absence of a "control group" and a "calibration measurement" this research approach cannot be classified as an experiment and thus should be regarded as a quasi-experiment.
} 
answers They were asked to state whether the project was a success or a failure and to rate success on a scale from 1 to 100 . This resulted in a dataset with 650 binary datapoints (success or failure) and a dataset with 650 scores.

\section{Data Analysis method}

The data are analysed using a technique proposed by Vanhoof ( Vanhoof \&all 2005) in a customer satisfaction study. The technique evaluates the contribution of the success criteria in a two-stage evaluation process. First the evaluation process is modelled and then, in the second stage, the model is used to determine and quantify the contributions of the criteria.

\subsection{Aggregation theory: uninorms}

Aggregation operators serve as a tool for combining various scores into one numerical value. An important class of aggregators, called representable uninorms, posses additive generators $\mathrm{g}:[0,1] \rightarrow[0,1]$ which define the uninorm via :

$$
\mathrm{U}(\mathrm{x}, \mathrm{y})=\mathrm{g}^{-1}(\mathrm{~g}(\mathrm{x})+\mathrm{g}(\mathrm{y}))(1)
$$

Dombi (Dombi 1982) showed that if $\mathrm{g}(\mathrm{x})$ is the generator function of the uninorm operator then the function displaced by $\alpha: \mathrm{g}(\mathrm{x}+\alpha)=\mathrm{g}_{\alpha}(\mathrm{x})$ also possesses the properties of the generator function. The neutral value ' $\mathrm{e}$ ' naturally varies, which allows the formation of uninorm operators with different neutral values from one generator function. The generator function used contains one parameter whose value needs to be determined from the data. Consequently, for every expert evaluation the neutral value can be determined and the individual evaluation function can be constructed, which is a uninorm. This approach has the advantage that there is a higher sensitivity for differences between experts .

\subsection{Calculating contributions of criteria, based on the full set of project evaluations}

The contribution of criterion $x_{j}$ for expert $\mathrm{i}$ can be defined by the following difference :

$$
\text { Contrib }(\mathrm{i}, \mathrm{j})=\mathrm{E}_{\mathrm{i}}\left(\mathrm{x}_{1}, \ldots ., \mathrm{x}_{\mathrm{n}}\right)-\mathrm{E}_{\mathrm{i}}\left(\left(\mathrm{x}_{1}, \ldots ., \mathrm{x}_{\mathrm{j}-1}, \mathrm{e}_{\mathrm{i}}, \mathrm{x}_{\mathrm{j}+1}, \ldots, \mathrm{x}_{\mathrm{n}}\right)\right.
$$


with $E_{i}$ the uninorm of expert i. In fact the effect of replacing the criterion score by the neutral score is calculated. This effect can be positive or negative. As a consequence the histogram of all the contributions for a certain criterion will be bimodal. This histogram is characterized by three numbers: the total average value (called mean), the average value of the positive contributions (called pos) and the average value of the negative contributions (called neg).

The results of all evaluations are presented in Table 1.

Table 1: Overall results

\begin{tabular}{|c|c|c|c|c|c|c|c|c|}
\hline & \multicolumn{2}{|c|}{ Users } & \multicolumn{2}{|c|}{ projectteam - } & \multicolumn{2}{|c|}{ projectteam - } & \multicolumn{2}{|c|}{ management } \\
\hline & & & \multicolumn{2}{|c|}{ no benefactors } & \multicolumn{2}{|c|}{ benefactors } & \multirow[b]{2}{*}{ mean } & \multirow[b]{2}{*}{ neg, pos } \\
\hline & mean & neg, pos & mean & neg, pos & mean & neg, pos & & \\
\hline on time & -0.3 & $-19.9,16.5$ & 1.6 & $-17.5,16.1$ & 1.8 & $-18.5,17.4$ & 0.9 & $-19.1,16.6$ \\
\hline $\begin{array}{l}\text { within } \\
\text { budget }\end{array}$ & -0.5 & $-18.5,14.5$ & 0.6 & $-17.1,14.1$ & 1.0 & $-16.9,14.8$ & 0.2 & $-16.9,13.6$ \\
\hline $\begin{array}{l}\text { to specifica- } \\
\text { tions }\end{array}$ & 3.3 & $-14.7,15.9$ & 4.6 & $-12.6,15.5$ & 4.8 & $-13.5,16.7$ & 3.6 & $-13.0,14.9$ \\
\hline $\begin{array}{l}\text { Manage- } \\
\text { ment } \\
\text { happiness }\end{array}$ & -2.6 & $-21.0,17.5$ & -0.7 & $-18.0,17.5$ & -1.0 & $-18.6,17.7$ & -1.9 & $-19.5,17.1$ \\
\hline $\begin{array}{l}\text { projectteam } \\
\text { happiness }\end{array}$ & 0.2 & $-17.2,14.4$ & 1.5 & $-15.8,14.7$ & 1.7 & $-15.9,15.2$ & 0.5 & $-16.3,13.7$ \\
\hline $\begin{array}{l}\text { User } \\
\text { happiness }\end{array}$ & 0.5 & $-22.8,18.7$ & 2.6 & $-19.2,20.2$ & 1.8 & $-21.2,19.9$ & 0.7 & $-22.3,18.7$ \\
\hline $\begin{array}{l}\text { fin/com } \\
\text { success }\end{array}$ & -4.4 & $-22.6,18.9$ & -2.6 & $-19.8,18.1$ & -3.0 & $-20.2,18.4$ & -3.0 & $-19.9,18.4$ \\
\hline
\end{tabular}

In order to understand the mean values, the percentages of perceived successful and failing projects is given in table 2 .

Table 2: Global evaluations

\begin{tabular}{|c|c|c|c|c|}
\hline & Failing & $\begin{array}{l}\text { Mean neg. } \\
\text { scores }\end{array}$ & Succesful & $\begin{array}{l}\text { Mean pos. } \\
\text { scores }\end{array}$ \\
\hline Users & $38 \%$ & 34,9 & $62 \%$ & 62,3 \\
\hline Projectteam No benefactors & $37 \%$ & 32,8 & $72 \%$ & 70,0 \\
\hline Projectteam No benefactors & $36 \%$ & 36,1 & $70 \%$ & 67,9 \\
\hline Management & $32 \%$ & 30,7 & $68 \%$ & 68,0 \\
\hline
\end{tabular}


The mean value should be considered as a total impact measure. Table 1 indicates, for example, that for this set of project descriptions the criterion 'to specifications' has in general a positive impact for the users while the criterion 'fin / com success' has in general a negative impact. The absolute values of the negative contributions are greater than the absolute values of the positive contributions, which indicate that in absolute terms, the disfirmative effects exceed the affirmative effects. I.e. the reward for fulfilling a criterion is less compared to the punishment received for not fulfilling the criterion.

The span between the positive and negative contributions (= |pos - neg $\mid$ ) provides an insight into the impact of the different criteria on the judgement of the project. A large span implies that fulfilling a criterion contributes largely to the perception of success while failing to fulfil the criterion contributes to a perceived failure. Consequently, the larger the span, the more impact the criterion has on the judgement of the project. Table 2 indicates for example that for the users, the span for the criteria "user happiness" $(22,8+18,7=41,5)$ and "fin/com success" $(22,6+18,9=41,5)$ are equal and larger than the span of the other criteria. Consequently, the impact of both criteria on the judgement of a project is similar. Though, the high scores indicate that these are the most important criteria for the users.

"User happiness", "fin/com success" and "management happiness" are the three most important criteria for all groups examined. Though, the proportion between the criteria differs. This signifies that the groups involved use similar sets of criteria, though the impact of every criterion in the set of success criteria differs depending on the group examined.

Note that the criteria "to specifications" and "project team happiness" have a low span. Consequently, these criteria can be regarded as of little importance to the judgement of ICT projects.

\subsection{Comparing results}

Table 3 combines the results of a probability matrix decomposition model (Maris, De Boeck \& Van mechelen, 1996).

For every party involved and for every criterion the median of the PMD model and the positive contribution of the aggregated model are represented. The first indicates the probability that a criterion is perceived as necessary for success, the latter features the affirmation power of the criterion. 
Table 3: Comparing the results of the PMD model and the aggregation models

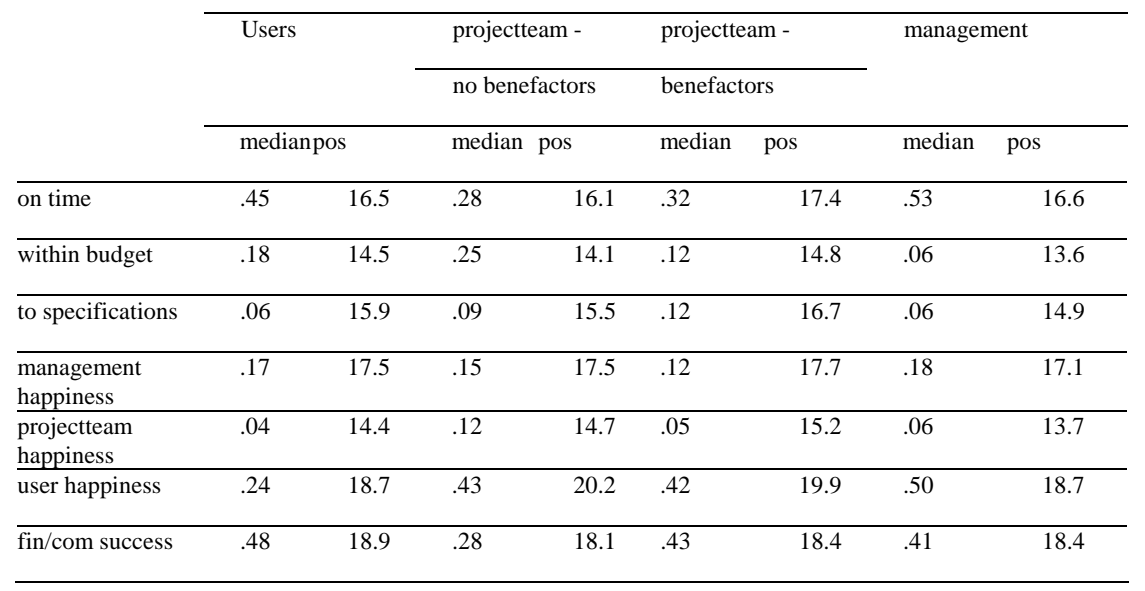

In general the figures do not contradict. Both techniques indicate that "user happiness" and "fin/com success" are the two most important criteria. They have a high mean for the PMD model and at the same time, they have a large positive contribution, indicating that their impact on the judgement of the project is important. Similarly, the criteria "to specification" and "project team happiness" are the least important factors. Though, the impact of the criteria "management happiness" and "on time" is less outspoken. Depending on the technique used, they have a slightly different place in the ranking of the criteria within the different groups.

\section{Conclusions}

Since none of the groups examined bases their judgement solely on the triple constraints, fulfilling them does not guaranty that the project is perceived as a success. Moreover, satisfying the predefined specification appeared to have little impact on the judgement of a project. This clearly demonstrates that other sets of success criteria should be applied. The results of this research indicate that the criteria "on time", "user happiness" and "fin / com success" should be incorporated in any set of criteria, developed to evaluate the success of ICT projects.

This research confirms that user satisfaction is a prime criterion for the end users. They want to work with the best (not optimum) application. They should 
be happy with the project's results. Though, in opposite to literature (see supra), this is not the sole criterion. Financial or commercial success equally influences their judgment. This indicates that besides their personal desires, the corporate goals are a user's concern as well.

Literature indicates that project team members are focusing on short term operational criteria. Though, this could only be confirmed partially. Not exceeding due date (criterion "on time") appeared to be a very important criterion for this group, while the other operational criteria such as "within budget" and "to specifications" have far less impact. Apparently, satisfying users and delivering fin/com success prevails over budgetary constraints and predefined specifications. Note that the emphasis on long term gains (fin/com success) is more outspoken for the project team benefactors compared to the project team no benefactors, as could be expected based on literature since the involvement of the latter ends at the handover of the project.

The management focuses on the long-term gains (financial or commercial success). Their company needs to make profit and every project should contribute. Though, the criteria "on time" and "user happiness" appear to be important as well. Possibly this is caused by the fact that the gains an ICT project generates are often not fully tangible.

\section{References}

1. Belassi, W., Tukel, O. I., 1996. A new framework for determining critical success/failure factors in projects, International Journal of Project Management, vol. 14., pp. 141-151.

2. Dombi, J., 1982. Basic concepts for the theory of evaluation: The aggregative operator, European Journal of Operational Research 10, pp. 282-293.

3. Fowler, A., Walsh, M., 1999. Conflicting perceptions of success in an information systems project, International Journal of Project Management, vol. 17, pp. 1-10.

4. Gelfand, A.E., Smith, A.F.M., 1990. Sampling based approaches to calculating marginal densities, Journal of the American Statistical Association, vol. 85.

5. Ingram, G., 2000. The way to enlightened project management, Project Manager Today.

6. Maris, E., De Boeck, P., Van Mechelen, I., 1996. Probability matrix decomposition models, Psychometrika, vol. 61, pp. 7-29 
7. Milis, K., Mercken, R., 2001. Implementing IS/IT technology: success factors, in proceedings $13^{\text {th }}$ International Society for Professional Innovation Management - conference.

8. Pinto, J.K., Slevin, D.P., 1989. Critical success factors in R\&D projects, Research technology management.

9. Turner, J.R., 1993. The handbook of project-based management, McGrawHill.

10. Vanhoof K. , P. Pauwels , J. Dombi , Brijs T.,Wets G, 2005. Penalty-Reward Analysis with Uninorms: A Study of Customer (Dis)Satisfaction (2005) in Intelligent Data Mining. Techniques and Applications. Editors: Ruan D., Chen G., Kerre E., Wets G, pp. 237-252.

11. Wateridge, J., 1995. IT projects: a basis for success, International Journal of Project Management, vol. 13, pp. 169-172.

12. Wateridge, J., 1996. Delivering successful IS/IT projects: eight key elements from success criteria to review via appropiate management, methodologies and teams, PhD. Henley management college, Brunel University.

13. Wateridge, J., 1997. Training for IS/IT project managers: a way forward, International Journal of Project Management, vol. 15, pp.283-288.

14. Wateridge, J., 1998. How can IS/IT projects be measured for success?, International Journal of Project Management, vol. 16, pp. 59-63.

15. Wright, J.N., 1997. Time and budget: the twin imperatives of a project sponsor International Journal of Project Management, vol. 15, pp. 181-186. 